\title{
USING CORRESPONDENCE ANALYSIS TO MAP ONLINE PURCHASE CRITERIA OF DIFFERENT PRODUCT CATEGORIES
}

\author{
Preeti Thakur \\ Jaypee University of Information Technology \\ thakurpreeti43@gmail.com \\ Anupriya Kaur \\ Jaypee University of Information Technology \\ anupriya.kaur@juit.ac.in
}

\begin{abstract}
This study aims to evaluate online product categories (electronics, apparels, personal care, kitchen appliances and stationery \& school/offices supplies) association with key purchase criteria to illustrate the relative positioning of five product categories across specific purchase criteria. The study includes a sample of 600 respondents from three tier 2 cities of north India-Kota, Agra, and Jalandhar. Correspondence analysis was used to depict purchase criteria based comparative analysis of the top selling online product categories. The findings of the paper helps to reflect on three aspects - (i) similarity in the positioning of product categories, (ii) specific purchase criteria association with product categories and (iii) dominant purchase criteria. This study provides meaningful insights for multi-category players and market space aggregator to create an efficient/effective marketing programs for obtaining sustainable competitive advantage. The study also presents an opportunity to reflect on the efficacy of its current strategy and optimally reposition itself. Also, the study presents a meaningful ground for future researchers who wish to investigate the growing potential of e-tailing in small town India.
\end{abstract}

Keywords: India, Tier 2 cities, E-tailing, Online attitude, Correspondence analysis.

\section{INTRODUCTION}

Globalization has led to the proliferation of the business opportunities across national borders. Several online players like Amazon and Walmart have expanded to emerging countries like India. Similar to other Asian nations, in the last few years the online market place in India is witnessing intensified competition with both domestic and international online players vying for consumer attention and aiming to acquire a greater market share [1]. There is a greater call on the companies to effectively manage the marketing process-beginning to end-for a competitive advantage. Given that marketing activities are a conscious effort to elicit a favorable response from the target market the point to ponder is - What kind of philosophy and strategy should they adopt to balance the interests of organization and consumers. Academic research can lend support in this direction and is elaborated in the upcoming sections. This study endeavors to present how with the emergence of new 
market segments, online marketers can provide the right stimulus to capture the new age market opportunities.

Furthermore, emerging markets work as a growth engine for multinational companies operating across globe. Economic growth and increasing purchasing power in emerging markets have great potential to significantly improve both local and global trade. Over the past two decades, there have been significant increases in global trade and cross-cultural pollination of ideas [2]. Asian and particularly populous South Asian nations like India offer great opportunities to develop new perspectives and practices in online marketing. Market such as of India which is highly heterogeneous given its vast geography and cultural diversity can help showcase how online marketers can design a suitable market strategy contextual to the market segments. E-tailing, which consists of online marketplaces and online retail, is one of the rapidly growing segment. Rising consumerism in small town India (later referred and explained as tier 2) led to the development of online market segments which have a vast and faster growth potential. The Indian online commerce market is expected to reach US\$ 64 billion by 2020 and up to US\$ 200 billion by 2026 from US\$ 38.5 billion [3] As the market saturate in tier 1 (metro) cities of India concurrently a number of tier 2 and 3 cities have been found to deliver a successful economic growth. Leading online players in India - Amazon, Flipkart and Snapdeal have claimed that a majority of orders come from tier $2 / 3$ cities or small towns. Amazon India currently present in more than 100 cities, plans to expand to another 60 tier 2-3 cities in the next 12-14 months [4]. Currently electronics is the biggest segment in online commerce in India followed by apparels, beauty \& personal care and books in the e-commerce retail industry [5]. Despite the fact, that internet user base largely include urban population, the semi-urban and rural user base is expanding with surging diffusion of internet and smart phones. The internet has arrived in lower tiers and small towns of India fuelled by emerging prosperity, consumption in these cities are growing rapidly, in comparison to the biggest cities. E-commerce has emerged as a potent leveler between urban, semi-urban and rural population. Unfortunately, this segment receives limited attention from practitioners or academic research. There are no visible models or strategic frameworks which can specifically address these segments.

Online marketers aiming to reach to tier 2 cities need to assess consumer perceptions and reflect on how to design their market offerings. In particular, the exploration of the association of commonly employed purchase criteria such asdiscounts, delivery option, delivery time, product visuals, exclusive offers etc. with different product categories may provide meaningful insight for optimal positioning. Insights on this can not only benefit domestic and local online players but also global players who want to do business in India. Additionally, market practitioners of Asian and South Asian region who aim to engage small town online consumers in their own countries may draw meaningful inferences from such insights and augment the possibility of similar strategies locally.

Marketers need to provide a right stimuli and suitably design their marketing mix. However, with intense competition businesses often feel compelled to bundle or replicate whatever are the current trends in their industry (e.g discounts) instead of developing a customer-focused value proposition. Decoding consumer behavior in market segments of interest and discerning the purchase criteria consumers associate with product and brand choices is an essential part to strategy formulation. This study 
attempts to evaluate online product categories (electronics, apparels, personal care, kitchen appliances and stationery \& school/offices supplies) association on key purchase criteria using correspondence analysis. The study focuses on three tier 2 cities- Kota, Agra and Jalandhar and seeks to present a visual and easily comprehensible view of the comparative positioning of the product categories vis a vis key purchase criteria. In essence it addresses -What is the underlying structure of the specific purchase criteria across the five product categories? The stakeholders of tier 2 online marketing would greatly benefit from a criteria based illustration of the association between various purchase criteria and different product category to reinvent their marketing strategies. In the sections that follow first, the backdrop of the study and a theoretical perspective on purchase criteria is discussed. Next, the research design and findings are presented. The concluding section discusses the findings and the theoretical/practical implications thereof.

\section{BACKDROP AND THEORETICAL PERSPECTIVE}

\subsection{Growing potential of tier 2 cities}

The Indian cities are segregated as tier 1, tier 2 and tier 3 and the division was made on the grounds of City Compensatory Allowance (CCA) and House Rent Allowance (HRA) on the basis of seventh central pay commission' Government of India [6]. The population was set as the benchmark for the segmentation and cities were classified as tier 1 - population above 50 lakhs, followed by tier $2 / 3$ having population in between 5-50 lakhs and small town comprising less than 5 lakh population. As per the report Government of India (GOI), there are about 8 tier 1 cities (metro), 26 tier 2 cities, 33 tier 3 cities and over 5000 tier 4 towns. Obvious to say much of India's population currently lives in tier 2 and tier 3 cities. A noticeable aspect from a business point of view is the difference in retail dynamics in metros and tier 2 cities. Although e-commerce and physical stores will continue to co-exist in India, but e-commerce currently has a definite edge over physical retail in India's tier 2 and tier 3 cities [7].

Today, people in tier $2 / 3$ cities are leading a more aspirational lifestyle with apparels, consumer electronics and home appliances forming the bulk of orders, coming from these cities. Additionally fondness for brands among online consumers from tier 2 cities and unavailability of brands in these locations are further intensifying the growth of online shopping. Thus, it is of no surprise that online player Snapdeal for the year 2019 plans to majorly target tier 2 and smaller towns to draw new online shoppers [8]. A similar trend has been witnessed by Amazon India as they stated that "three times more new customers have shopped on the company's platform for the first time during this year, with a large portion of these customers coming from tier 2 and 3 cities [9]. Eventually, limited retail penetration and inadequate product and demographics of consumers (who are now internet users) are forming a "sweet spot" for the online marketers.

The EY report [10] revealed that 26.4 trillion of household income in India is concentrated in tier 2/3 markets as compared to 800 billion in India's big 8 metros. Evidently, there is a vast demand and supply gap in these fast emerging markets. Several reports from the industry reflect on the increasing economic potential on tier 2 cities, some are quoted below: 
- According to Boston Consulting Group [11] the tier 2/3 cities comprise almost $80 \%$ of sale in travel industry by 2020 .

- A report by E travel Marketing India [12], 2015 has been revealed that 37\% of hospitality in India wants to grow in tier 2 cities.

- A report [13] stated that the business activities are shifting from tier 1 to tier 2 cities and requirement for office space in these cities are growing rapidly.

- The property searches in 2018 also surge $173 \%$ in tier 2 cities during the first quarter of 2018 compared to the first quarter of 2017 [14].

As discussed earlier, it is evident that tier 2 cities have become an attractive market segment for online marketers and it has captured the attention of marketers worldwide. Not just India, emerging markets are the present focus while the last three decades were all about marketing in developed countries [2]. In today's global economy, emerging markets are the growth engines in the world and often the primary targets of doing business. The most prominent emerging markets are China and India. Both the countries have already emerged as largest and third largest economies in the world in terms of purchasing power [15]. Emerging economies such as China, India, Malaysia and Indonesia have witnessed tremendous growth in tier 2 markets in the last two decades [16]. E-commerce growth in China is driven by lower tier cities and these lower tier cities has seen significant growth as emerging middle income group consumers with limited access to physical retail outlets turn to ecommerce [17]. Penetrating domestic markets deeper (geographically) is an universal strategy among marketers in contemporary times [18]. Online retailers need to continuously examine and re-examine their business strategies to meet the changing expectations of tier $2 / 3$ and small town consumers. Consumers' expectations from tier 2 cities from online retailers are shifting due to varying dynamics of retail environment (online and offline) including the entry of bigger players.

It is essential for online marketers to know their customers from tier $2 / 3$ cities (expectations or online decision criteria) and capitalize on gaps that offline retailers do not provide. Presently, pricing and discounts remain the focus of online marketers as a key strategy. It may be good in short run but not enough to retain its customers for long run. In particular they need to build a positive attitude for online shopping amidst its target customers. Indian e-commerce market is dominated by larger online players such as Flipkart, Amazon, Snapdeal and these players can easily promote the heavy discounting model compare to smaller players. Evidently, many of the online players need to reinvent across aspects like product quality, variety, service support etc. and come up with the newer models based on consumer profiling. However despite the growing potential of tier $2 / 3$ cities, this segment has been academically unexplored. The present study can generate few meaningful results for online players as the study explores the efficacy of several purchase criteria as perceived by consumers from tier 2 cities. Thus, assessing consumer perceptions on specific aspects of the organization's current marketing strategy is essential to develop programs and strategies for a lasting consumer engagement. This study provides insights on the same.

\subsection{Purchase criteria}

The idea of buying some product or services often is not sudden but carries a process of thinking, analyzing options, and taking other factors in account to reach to 
a buying decision. Thus it is of no surprise that, marketing decision makers spend more money than ever to understand who buys? why do they buy? when do they buy? where do they buy? why do they buy? [19]. Several theories/model such as - Theory of Reasoned Action, Engel, Kollet, Blackwell (EKB) Model and Stimulus response model throw light on this phenomenon. The same are discussed briefly and form the theoretical underpinnings of this study.

The core of the Theory of Reasoned Action posits that consumers act on behavior based on their intention to create or receive a particular outcome. In this analysis, consumers are rational actors who choose to act in their best interests [20]. In the case of online purchase, consumer seek a customer-focused value proposition as an outcome and as rational beings are perceptive to various purchase stimuli or criteria to make a sound decision. Similarly, the EKB model suggests that once aware about products and brands consumers transcend to the decision-making stage, choosing to make a purchase based on rational insight. At this stage they process the variables and external influences (i.e the purchase criteria) to make a sound judgement [21], [22]. The stimulus response model of consumer behaviour is the most useful to understand the interplay of purchase criteria in the context of individuals buying consumer products. It shows marketing stimuli as input and buyer response as output with the process of decision-making in the middle which depends on the buyer's characteristics [23],[24]. Several purchase criteria such as- discounts, delivery option, delivery time, product visuals, exclusive offers etc act as marketing stimuli to lead to the expected outcome of a purchase decision from the prospective consumer. Buyer characteristics influence this process and therefore it cannot be generalized. It is for this purpose that focus of this study is on consumers from tier 2 cities.

Marketers employ a variety of tools, tactics and strategies to elicit a favorable response from their target group and secure a competitive position. On the other hand consumers employ various purchase criteria to make a decision. It is imperative for marketers to factor these for optimal positioning. The aspect that customers place the most value on when making an online purchasing decision is known as customers' key purchasing criteria [25]. These criteria can be associated with any of the mixtures of attributes related to a purchase options or alternative [26], [27]. Previous researchers [28], [29] have classified the purchase criteria as being utilitarian or objective (warranty, well-known brand, performance, low price, durability and reliability) and hedonistic or subjective (style/appearance, prestigious brand, referent quality and value).

To the authors knowledge there has been hardly any study which maps the association of purchase criteria with respect to different product categories in an online marketspace or otherwise. However an attempt is made to present the perspectives from the literature on the efficacy of purchase criteria in consumer decision making. Extant literature suggests that the relative importance of the evaluative purchase criteria might differ by buying situation [30], [31], interest level [32], [33], type of options evaluated [34], [35], and amount of buying experience [36], [37]. Further, studies from different works of literature show that availability of various merchandise, their price, discounts, return policy, online reviews and originality are essential purchase criteria [38], [39]. Research in the past revealed that a generous return policy enhance customers' confidence level and it would boost sales revenue by persuading more and more customers to shop [40], [41]. Similarly a study 
on online reviews revealed that future product sales and consumer's purchase decision are positively correlated with online reviews and revealed that maximum of online shoppers finalizes their buying decisions by reading reviews [42], [43].

An online business intelligence portal- Statista had ranked the purchase criteria that consumers' employ when buying luxury goods and it suggests - quality, price, brand name, exclusive offers, labels and latest characteristics are highly relevant to purchase criteria among US online consumers. Another study [44] investigated female fashion followers and their attitudes toward buying apparel and found that women shoppers give importance to six purchase criteria: durability, quality, price, good fit, ease of care and comfort. Additionally modern consumers prefer comparing (online vs online and online vs offline) products from one to another on the basis of certain criteria prior to making a purchase. A study [45] explored the role of online infomediaries for consumers about information mediation and price comparison and found that high-involvement consumers target on a systematic cues while evaluating the quality of a product. However, when they realize that their initial search generates incomplete output, causing them to believe more product functional risk, they look for further cues. Additionally a consumer who will be highly involved in a product would be interested in knowing and exploring entirely about it prior to making a purchase. Hence consumer, starts comparing the various models and brands available on different online-offline outlets, investigate, and looks forward to the reviews and recommendations.

Purchase criteria such as delivery information (delivery option and delivery time) have been considered very important by online consumers e.g. PageThomas [46], has studied the European and Western online consumers with regard to the importance of delivery information while making a purchase online and the study revealed that online consumers rate delivery schedules and delivery guarantees as the critical delivery information. A reliable product information and product delivery are very important to strengthen customer service confidence and trustworthiness. The customers purchase directly from the manufacturer (in internet driven sale supply chain) sacrificing the benefit of personal examination of the product. It leads the likelihood that customers will have some complaint regarding the product and would like to return it and to handle such situation online marketers need to have a clearly written return policy [41]. The impact of return policy on online decision making is not extensively explored, especially for online sales in tier 2 cities in India thus, return policy of online marketers has also included in the purchase criteria list in the current study.

In the literature product visualization is considered one of the most important decision making criteria for product categories such as online apparel, since the garments/apparel is a product that demands various types of visual presentation and sensory evaluation, thus visualization plays a vital role while making online apparel purchase decision [47]. Eliminating the possible high shopping risk of apparel products by applying features which help the online shoppers to sense as if they are actually interacting with the product is becoming more and more critical to the success of apparel e-businesses [48]. McCormick andLivett [49], revealed two main elements which form unique experiences for the consumer in order to examine or viewing apparels online, in which the first one identified functional product viewing, second area identified the hedonic effects. Past studies have recommended that online 
marketers must connect hedonism with utilitarianism in order to produce a gratifying online purchasing experience [50]

Though past studies have revealed many important purchase criteria unfortunately few important criteria have been unexplored which are highly influential in tier 2 online consumer settings [51]. The present study is typically based on online consumers from tier 2 cities and attempted to explore all the purchase criteria that are relevant in tier 2 cities such as unavailability of branded products offline, product variety, ease of placing orders, payment options, appropriate price range and sales \& support system etc. These purchase criteria serve as rational patronage motives for consumers hence need an empirical investigation in Indian tier 2 market.

The current tier 2 shopping trends (discussed in the previous section) indicates the shift in consumer expectations and behaviour, leading to increasing adoption of online commerce as a habit in these areas. Amidst such a supportive scenario it becomes pertinent for online retailer to know their online consumers and the kind of perception they hold towards various product categories which are available on online portals. Thus, the study has mainly focused on Indian tier 2 cities and attempted to understand their online purchase behavior/decision making while selecting specific product categories.

\subsection{Product categories}

Online consumer buying behaviour is defined as a type of behaviour which is exhibited by customers while browsing websites of an e-tailer in order to search, select and purchase goods and services, in order to fulfill their needs and wants [52]. Consumer buying behaviour varies with the level of involvement and type of product they buy. Consumers consider different purchasing attributes to each different product category [53]. It is expected that the buying behaviour of consumers (metro) will be different form (tier 2/3 or small town) e.g. a study on Skyworth TV-Channel Dynamics and Growth- in China's rural market revealed that high technology, brand reputation, applications and user friendliness were the major important decision criteria for metropolitan consumers while consumers in small town and cities were more price sensitive and they were more concerned about after sale services. It was also revealed that the choice criteria varies by product a consumer is willing to purchase [54]. Similarly, another study from Jordan revealed that consumer look for the purchase criteria such as- enjoyment, personalization, price when making the purchase of smart home devices [55]. Therefore an understanding of association or various purchase criteria with the product categories is critical.

It is widely acknowledged that marketers segregate products on the ground of tangibility, durability and use (industrial or consumer) which eventually helps shape the marketing mix strategy. Therefore, the study examines a set of generic purchase evaluative criteria for a variety of consumer products available online: electronics, apparels, personal care, kitchen appliances and stationery \& schools/offices supplies. The product categories were chosen to reflect upon a wider set of products in terms of durability, expressiveness and necessity. Also, the purchase criteria employed in this study can be suitably applied to these product categories. The categories are described below: 
- Electronics category includes laptops, desktop computers, printers, smartphones, camera, flat screen TVs, audio/video players, remote control cares, video games etc.

- Apparels category includes wear of all ages (men, women and kids) for all occasion.

- Personal care category includes cosmetic products (men and women) such as cleansing pads, cotton pads, deodorant, eye liner, hair clippers, facial cleanser, lipstick, body lotion, makeup, body wash, perfumes, nail files, shaving foam, razors, moisturizers of various brands.

- Kitchen appliances category includes water purifiers, dishwashers, refrigerators, water heaters, microwave ovens, kitchen stoves, washing machines, trash compactors, induction cookers and others utensils.

- $\quad$ Stationery \& schools/offices supply product category includes items such as copying paper, writing paper, coloured boxes, message pads, pens, pencils, highlighter, permanent markers, glue sticks, notepads, envelopes, planners, calendars, sticky notes, correction fluid, and other office supplies.

\subsubsection{Electronics}

The electronic category is the first one among the five product categories studied. Electronics products are described as products which are purchased by consumers for their own use. According to consumer electronics society electronics category consists products like TVs, cellular phones, audio/video players, cameras, home security systems, etc [56] Traditionally electronics products were perceived as complicated and costly products that require physical examination prior to purchase [57]. Presently, the domestic segment for consumer electronics and durables sector have witnessed substantial growth over the last few years and electronics products are the most selling products on Indian e-commerce market [58]. Leading online players in India like Flipkart, Amazon and Snapdeal have time and again reported the growth in tier 2 cities [59]. Previous researchers [60], [61], have considered consumer electronics as high involvement products which have a higher risk (as perceived by consumers). Across online shopping, the failure to check the product prior buying and absence of personal contact/relation with the shopping assistant may pose certain challenges. It is therefore critical to assess its association with key purchase criteria which can guide its success in the online market.

\subsubsection{Apparels}

Apparel product category includes wear for all ages (men, women and kids) and for multiple purpose such as; party wear, casual wear, formal wear, traditional dresses, fashion apparels etc [62], [63]. In the initial studies which focussed on online shopping [64], [65], [66], experiential products, such as apparel, were referred as the product items which would never be sold online. Conflicting to early beliefs ecommerce apparel business has seen a great success in recent years. According to a report- online apparel sale are expected to increase at phenomenal growth rate in upcoming years and it is believed that maximum of revenue in Indian online commerce will come from apparels and fashion e-commerce [67]. Research studies have found that consumers who buy apparel online especially fashion consumers are 
pleasure aspirants and purchase apparels for hedonic reasons [68], [69]. Hedonism has entrenched in modern-day life style and culture as a right to engage in pleasure and fun seeking exercise for the pursuit of enjoyment, happiness and immediate gratification [70]. Additionally, it has been revealed by previous researchers [48], [71], [72] that a huge number of garments and apparels consumers still believe that nothing can replace shopping in a brick and mortar store. It is therefore critical for online marketers to adequately connect the hedonism with practical utilitarianism to produce a gratifying online buying experience.

\subsubsection{Personal care}

Personal care product category includes cosmetic products (men and women) such as cleansing pads, deodorant, lipstick, lotion, makeup, facial cleanser, body wash, perfumes, moisturizer etc for women and products such as hair coloring, toning gel, bronzing products face creams and many more for men [73]. In the last few years, marketers have witnessed the growing interest in consumption practices of appearance related products and changes regarding vanity products. In addition, a recent investigation revealed that consumption of cosmetics and personal care surged noticeably at the outset of the new millennium [73], [74]. Internet has provided impetus to change the way people shop and perceive personal care products e.g. the personal care category was traditionally associated with female but recently a sharp increase in the demand for these products by men has been seen. The male personal care market is growing rapidly and is progressively representing an important opportunity for all marketers operating in cosmetic and personal care industry [75]. Furthermore, MNC brands are no longer preferring to manufacture the stereotypical man products, such as razors and shaving foam, but are now concentrating progressively on making niche products. Previous studies [74], [76] have found importance of purchase criteria in personal care segment and it revealed - visual appeal, price, usage experience, brand image and social influences as few important criteria. Presently the marketers of personal care and cosmetics products in India are faced with decision of how to accelerate the diffusion and increase the usage and sales of their products. Thus it becomes pertinent to identify the purchase criteria which associates itself with this category in online purchase decision making.

\subsubsection{Kitchen appliances}

India has a huge base of the working consumers who hardly get time for conventional cooking because of having busy work schedules, thereby generating massive demand for high tech kitchen appliances usually developed and innovated in western countries that help them in easy and fast cooking. Consumers' increasing concern in improving the quality of life has motivated dietary/healthy consumption and well-being areas [77]. Kitchen appliances which include products like water purifiers, freezers, refrigerators, kitchen stoves, microwave ovens, and induction cookers etc have seen a sharp increase in online sales. Previous researchers [78], [79] have considered Indian middle class consumers to be the most influential segments triggering the sales of technologically advanced products and consumers' lifestyles have emerged one of the most important variables as demand for the household items such as- kitchen appliances facilitate consumers to invest their valuable time with more effectively and efficiently. Several kitchen appliances companies give primary 
importance only to high-tech and upgraded attributes for the betterment and convenience of consumer, failing to identify the importance of additional purchase criteria. Hence it is relevant to study such a fast growing product category and to assess its association with key purchase criteria which can guide its positioning strategy.

\subsubsection{Stationery \& schools/offices supplies}

India has a profitable stationery market for various renowned brands simply because of the large population and its sheer size. The stationery market in India is expected to grow rapidly in coming years [80]. Many Indians and international brands are competing to penetrate and tap this lucrative market to the hardest. This sector was considered once a prerogative of a few has today become a highly cluttered market. Stationeries commonly consist items such as writing paper, coloured boxes, pens, highlighter, notepads, envelopes and other office supplies. Past researcher [81] had revealed price as a critical attribute that effect and influences purchasing decision and consumers have ranked price on the top in attribute list when buying stationery items. The second position goes to the brand name followed by physical attractiveness. Although stationery product category is very lucrative and promising market unfortunately, there are very few studies in the past literature focusing on this category. Thus, the study aims to highlight purchase criteria of the stationery product category which might be critical for the practitioners for formulating marketing programs by leveraging the proper understanding of the digital consumer living in tier 2 cities or to competitively positioning themselves in market place.

\section{RESEARCH OBJECTIVE AND RESEARCH QUESTIONS}

Contemporary organizations strive to adapt to the ever changing marketplace and the challenges thereof. Strategic planning and careful management of the marketing offerings is the way ahead. This calls from moving away from a standard and stereotype market offering and identifying the gaps in the present strategy. Organizations which specifically aim at some particular market segments for instance tier 2 cities should not impose some of their standard marketing practices followed in metropolitan markets without reflecting on the response it elicits in the market segment. Also, consumption behavior varies with respect to product type. If consumers favor discounts for one product type they may be looking for warranties or service support for another product. What then becomes a valuable buying proposition for a consumer from tier 2 city? Is it same or different across different product categories? This calls for an empirical investigation. The primary objective of this research is to capture the marketplace dynamics of consumption in context to specific product categories- electronics, apparels, personal care, kitchen appliances and stationery \& school/offices supplies. This study addresses the following research questions:

RQ1:Are the product categories- electronics, apparels, personal care, kitchen appliances and stationery \& school/offices supplies positioned similarly or differently based on the several purchase criteria?

RQ2: What are the specific purchase criteria which relate to a particular product category? 
RQ3:Which are the purchase criteria that are discriminatory and have a dominant impact in the positioning of product categories?

\section{RESEARCH METHODOLOGY}

\subsection{Data collection and sample profile}

The online product positioning of five product categories - electronics, apparel, personal care, kitchen appliances and stationery \& school/offices supplies has been evaluated and the study was carried out in three tier 2 cities (Kota, Agra and Jalandhar) of northern India. The non-probability sampling technique was used for conducting the sampling process where two stage sampling was done. Firstly, area sampling was conducted in which authors selected three tier 2 north Indian cities- Kota, Agra and Jalandhar. Next data on specific location was collected with convenient sampling technique, recommended by the previous researchers [82], [83], [84]. It helps to gather the data in much shorter time compare to other techniques and this technique is a great alternative when funding is not available. Additionally, it is very beneficial for pilot studies which can be used as pointers and should help in the decision for further actions. The cities were selected on the basis of various reports and articles which have considered these cities as growing segment for marketers [85], [86], [87]. According to the report, people of Jalandhar are frequent online buyers with huge demands for products such as lifestyle and fitness equipment items [88]. A leading online shopping portal has listed the Jalandhar city on the top in e-commerce hub among other cities of Punjab [89]. Agra city is considered heaven for the shoppers, hence included in the present study. As a result of technological advancement and evolution of modernization, the city has entered on the top in the list of online marketers and gaining good growth potential [90]. The third city where the study has conducted is Kota as it is considered one of the fastest growing e-commerce market and is also popular for providing coaching for several competitive examinations with huge number of student base which has captured marketers attention [91]. The data was collected in the year 2018 across cities in the period between October- December, 2018. The field researcher approached the mixed age group of online buyers across cities i.e. Kota, Agra and Jalandhar. The sample composed of 200 each for the three tier 2 cities. Table 1 presents the sample composition.

Table 1. Sample Profile

\begin{tabular}{lccc}
\hline \multicolumn{1}{c}{$\begin{array}{c}\text { Socio Demographic } \\
\text { Variables }\end{array}$} & $\begin{array}{c}\text { Kota } \\
\text { Frequency }(\%)\end{array}$ & $\begin{array}{c}\text { Agra } \\
\text { Frequency }(\%)\end{array}$ & $\begin{array}{c}\text { Jalandhar } \\
\text { Frequency }(\%)\end{array}$ \\
\hline $\begin{array}{l}\text { Gender } \\
\text { Male }\end{array}$ & $143(71.5)$ & $157(78.5)$ & $113(56.5)$ \\
Female & $57(28.5)$ & $43(21.5)$ & $86(43)$ \\
\hline Age Groups & & & \\
$18-24$ & $110(55)$ & $110(55)$ & $104(52)$ \\
$25-31$ & $46(23)$ & $42(21)$ & $51(25.5)$ \\
$32-38$ & $24(12)$ & $21(10.5)$ & $26(13)$ \\
$39-45$ & $14(7)$ & $13(6.5)$ & $9(4.5)$ \\
Above 45 years & $6(3)$ & $14(7)$ & $10(5)$ \\
\hline
\end{tabular}


(cont.)

\begin{tabular}{|c|c|c|c|}
\hline $\begin{array}{c}\text { Socio Demographic } \\
\text { Variables }\end{array}$ & $\begin{array}{c}\text { Kota } \\
\text { Frequency }(\%)\end{array}$ & $\begin{array}{c}\text { Agra } \\
\text { Frequency }(\%)\end{array}$ & $\begin{array}{c}\text { Jalandhar } \\
\text { Frequency (\%) }\end{array}$ \\
\hline $\begin{array}{l}\text { Occupation } \\
\text { Government Job } \\
\text { Private Job } \\
\text { Businessman } \\
\text { Student } \\
\text { Housewife } \\
\text { Other }\end{array}$ & $\begin{array}{c}12(6) \\
69(34.5) \\
14(7) \\
98(49) \\
7(3.5) \\
0\end{array}$ & $\begin{array}{c}13(6.5) \\
52(26) \\
13(6.5) \\
105(52.5) \\
13(6.5) \\
4(2)\end{array}$ & $\begin{array}{c}3(1.5) \\
86(43) \\
4(2) \\
99(49.5) \\
7(3.5) \\
1(0.5)\end{array}$ \\
\hline $\begin{array}{l}\text { Family income (annual, } \\
\text { in Rs.) } \\
\text { Below } 6 \text { lack } \\
6-8 \text { lakh } \\
8-10 \text { lakh } \\
\text { 10-12 lakh } \\
\text { Above } 12 \text { lakh }\end{array}$ & $\begin{array}{c}143(71.5) \\
37(18.5) \\
8(4) \\
7(3.5) \\
5(2.5)\end{array}$ & $\begin{array}{l}135(67.5) \\
36(18) \\
11(5.5) \\
3(1.5) \\
15(7.5)\end{array}$ & $\begin{array}{c}88(44) \\
53(26.5) \\
29(14.5) \\
13(6.5) \\
17(8.5)\end{array}$ \\
\hline $\begin{array}{l}\text { Frequency of browsing } \\
\text { weekly } \\
\text { Once } \\
\text { Twice } \\
\text { Thrice } \\
\text { Daily }\end{array}$ & $\begin{array}{c}72(36) \\
67(33.5) \\
35(17.5) \\
26(13)\end{array}$ & $\begin{array}{c}65(32.5) \\
37(18.5) \\
32(16) \\
66(33)\end{array}$ & $\begin{array}{c}54(17) \\
40(20) \\
67(33.5) \\
39(19.5)\end{array}$ \\
\hline $\begin{array}{l}\text { Frequency of purchase } \\
\text { Once in month } \\
\text { Twice in month } \\
\text { Thrice in month } \\
\text { More than thrice }\end{array}$ & $\begin{array}{c}120(60) \\
55(27.5) \\
13(6.5) \\
12(6) \\
\end{array}$ & $\begin{array}{l}98(49) \\
54(27) \\
28(14) \\
20(10) \\
\end{array}$ & $\begin{array}{c}121(60.5) \\
48(24) \\
15(7.5) \\
16(8) \\
\end{array}$ \\
\hline $\begin{array}{l}\text { Average amount spent } \\
\text { in a month }(R s) \\
\text { Less than } 2000 \\
2000-4000 \\
4000-6000 \\
\text { More than } 6000\end{array}$ & $\begin{array}{c}110(55) \\
73(36.5) \\
12(6) \\
5(2.5)\end{array}$ & $\begin{array}{c}88(44) \\
59(29.5) \\
31(15.5) \\
22(11)\end{array}$ & $\begin{array}{c}92(46) \\
69(34.5) \\
23(11.5) \\
16(8)\end{array}$ \\
\hline $\begin{array}{l}\text { Preferable mode of } \\
\text { payment } \\
\text { Credit card } \\
\text { Debit card } \\
\text { Mobile wallets } \\
\text { Net banking } \\
\text { Cash on delivery } \\
\text { Other }\end{array}$ & $\begin{array}{c}28(14) \\
30(15) \\
5(2.5) \\
34(17) \\
103(51.5) \\
0\end{array}$ & $\begin{array}{c}23(11.5) \\
28(14) \\
9(4.5) \\
13(6.5) \\
127(63.5) \\
0\end{array}$ & $\begin{aligned} 22 & (11) \\
46 & (23) \\
4 & (2) \\
17 & (8.5) \\
111 & (55.5) \\
& 0\end{aligned}$ \\
\hline
\end{tabular}

\subsection{Survey instrument}

The data was collected with the help of a structured questionnaire. The field researcher approached the respondents (active online shoppers), briefly told the objective of the current study, and appealed them to engage in the survey. Earlier a pilot study of 100 respondents from Jalandhar (active online shoppers) was conducted 
which helped authors to provides valuable feedback so that researchers can revise or rework on the instrument designed for data collection. Only minimal changes were necessary. Subsequently, data was collected across the three selected tier 2 cities. This was followed by missing data analysis and tests for normality. In the initial stage of data collection the field researcher ensured that field survey grabbed information only from those respondents who were frequent online shoppers and often visited the online shopping sites. The aim of filter questions was to minimize the biasness related to online shopping behaviors/attitude that may obfuscate the analysis. The first section of questionnaire included the socio-demographic information and in the next section, respondents were asked to evaluate the association of nineteen purchase criteria (Table 2) for each product category (electronics, apparels, personal care, kitchen appliances and stationery \& schools/offices supplies). Statements such as- availability of discount options in various products, exclusive offers available to various products, availability of delivery options, easy return policy etc were measured on a five point likert scale (where; $1=$ strongly disagree, $2=$ disagree, $3=$ neither agree nor disagree, $4=$ agree and $5=$ strongly agree). This resulted in a total of 600 usable questionnaires which later were coded and interpreted with SPSS 24.0.

\subsection{Statistical analysis}

The correspondence analysis, a statistical visualization analytical technique, was employed for data analysis. This technique provides extraordinary flexibility in term of the form of data it can study or analyze. The only data demand for this technique is a contingency table of non-negative entries [92]. The purpose of this statistical analytical technique is to depict data geometrically in low-dimensional space [93]. It generates spatial maps that offer insights into similarities and differences within the objects and purchase criteria [94]. To match the requirement or condition of correspondence analysis the metric data (purchase criteria) was changed in binary form data [95]. The scale items were measured on a 5 point scale and therefore resulted in respondent scores ranging from 1 to 5 with a higher value in the scale (i.e. $3,4,5)$ specifying a favourable inclination towards a specific criterion whereas lower value (i.e. 1,2) specifying an unfavourable inclination towards a specific criterion. The data were collapsed in the binary form with a code value of 1 defining scores higher than the mid-value and a code value as 0 for the rest. In the application of this technique the data which were collected from three tier 2 cities was pooled for analysis. The authors felt that this might cause the distorted results if the sample profile in all three cities is highly heterogeneous. Hence, to investigate the homogeneity of sample profile across cities, a chi-square analysis cross- tabulation was undertaken on socio-demographic variables (such as: age, gender, education and occupation). The outcomes revealed non-significant differences with respect to gender implying (gender) homogeneity of sample profile in all three locations. Further, although analysis found significant differences on occupation and age albeit with very weak associations as indicated by the values of Crammer V. Hence, the three sub samples were deemed as homogenous. 


\section{RESEARCH FINDINGS}

\subsection{Correspondence analysis}

In this section, firstly, we present the process and output of correspondence analysis. Next we synthesize the findings by addressing the three research questions. Correspondence analysis is a descriptive or exploratory technique designed to analyze simple two-way and multi-way tables containing some measure of correspondence between the rows and columns. The results of this technique provide information which is similar in nature to those produced by factor analysis techniques, and they allow one to explore the structure of categorical variables included in the table. The most common kind of table of this type is the two-way frequency cross-tabulation table. Its primary goal is to transform a table of numerical information into a graphical display, in which each row and each column is depicted as a point [96], [97], [98].

A step wise analysis was done and results are discussed next. To understand the underlying structure of the specific purchase criteria across the five product categories, the output of correspondence analysis- contingency table, dimensionality and most importantly perceptual map are very useful.

Table 2 is a two-way contingency table of frequencies achieved by collected responses from respondents. Table 2 illustrates the cell counts and it conveys how many times an individual criterion is related to an individual product category. The number in the first row and first column- 545 and it indicates that selection of electronic product category is strongly influenced by the criterion- discount option as 545 respondents which accounts for $6 \%$ of the total associations formed with the category $(545 / 8,352)$ and almost $27 \%$ of all association with discount option $(545 / 1,991)$. The row and column marginal subtotal in the mentioned table label the number of times a criterion scores for individual criterion and product category, respectively. For example, as presented in Table 2, kitchen appliances recorded the highest (column table) with a score of 8,415, this category accounted for approximately $23 \%$ (i.e. $8,415 / 35,442$ ) of all the associations made with all the product categories across the 19 purchase criteria. Likewise two of the criterion "product information" and "return policy" were strongly related across categories with a marginal profile value of about 6 percent (i.e. 2,439/35,442 and 2,429/35,442). Further, "delivery time" had a poor scoring with just $3 \%$ association (i.e. $1,216 / 35,442$ ) across all product categories. A closer investigation finds that the case is especially poor for apparels with just $9 \%$ positive reply for this item. 
Table 2. Contingency Table

\begin{tabular}{lcccccc}
\hline \multicolumn{1}{c}{ Purchase Criteria } & Electronics & Apparels & $\begin{array}{c}\text { Personal } \\
\text { Care }\end{array}$ & $\begin{array}{c}\text { Kitchen } \\
\text { Appliance }\end{array}$ & $\begin{array}{c}\text { Stationery, } \\
\text { schools/offi } \\
\text { ces supplies }\end{array}$ & $\begin{array}{c}\text { Row } \\
\text { total }\end{array}$ \\
\hline Discount option & 545 & 500 & 296 & 500 & 150 & 1991 \\
Exclusive offers & 544 & 230 & 150 & 400 & 133 & 1457 \\
Comparison option & 500 & 200 & 220 & 330 & 286 & 1536 \\
Delivery option & 550 & 300 & 330 & 511 & 200 & 1819 \\
Delivery time & 200 & 120 & 233 & 336 & 327 & 1216 \\
Return policy & 540 & 515 & 555 & 560 & 259 & 2429 \\
Brand availability & 500 & 378 & 200 & 555 & 180 & 1813 \\
Payment option & 556 & 234 & 232 & 499 & 180 & 1701 \\
Ease of placing orders & 223 & 299 & 300 & 500 & 189 & 1511 \\
Appropriate price & 392 & 555 & 444 & 511 & 232 & 2134 \\
Sale \& support & 575 & 222 & 185 & 512 & 181 & 1675 \\
Online reviews & 540 & 281 & 240 & 511 & 499 & 2071 \\
Product varieties & 466 & 565 & 566 & 256 & 189 & 2042 \\
Product visual & 189 & 500 & 559 & 270 & 233 & 1751 \\
Product information & 577 & 367 & 488 & 553 & 454 & 2439 \\
Clarity of market & & & & & & \\
communication & 513 & 268 & 231 & 543 & 224 & 1779 \\
Hedonism & 257 & 554 & 545 & 186 & 555 & 2097 \\
Image of online player & 505 & 338 & 307 & 553 & 273 & 1956 \\
Shipment charges & 180 & 540 & 550 & 349 & 334 & 1953 \\
& & & & & & \\
Column Total & 8352 & 6966 & 6631 & 8415 & 5078 & 35442 \\
\hline
\end{tabular}

\subsection{Dimensionality}

The maximum number of dimensions for a correspondence analysis solution equals the smaller of the number of rows minus one or the number of columns minus one. In this study since the number of rows is 19 and the number of columns is 5 , the maximum number of dimensions is 4 . To determine the dimensionality of the solution, as in the case of factor analysis, the researcher investigate the eigen values and the cumulative proportion of variance explained by the dimensions [94]. As presented in Table 3, the first two dimensions developed in this study holds for $88 \%$ of the total variance. The addition of a third dimension improves the explained variance by $8.4 \%$, however for the sake of ease of display and interpretability a two-dimensional solution is retained here. Simply stated, two abstract underlying dimensions define the positioning and mapping of the product categories and purchase criteria.

A very important piece of information given by this technique is absolute contributions to variances of each dimension i.e what shapes these dimensions. These statistics indicate the percentage of variance explained by each row and column item (i.e. purchase criteria and product categories) in relation to each of the dimension. Due to the similarity of the algorithms, these statistics can be used, analogous to factor loadings in factor analysis, to interpret the dimensions. The larger the absolute contribution of an item to a dimension, the more important that item is in determining the underlying structure of that dimension [94], [99]. 
As displayed in Table 4, in dimension 1, the leading or dominating purchase criteria are- hedonism, product visuals, shipment charges, sale \& support and exclusive offers. Purchase criterion such as hedonism is adapted around the enjoyment and entertainment values that can be related through internet buying experience [49]. The findings reveal that hedonistic value emerges as a discriminatory criterion in online shopping. Product visual emerged as another important criterion which influences the positioning of the product. Thus, product visualizing can add to the foundation of a good experience, as higher levels of product visualization build up the consumer's sense of control which has a positive effect on both the usefulness of a website and perceived ease of use [100]. The higher levels of happiness and enjoyment which develop from the product visualization can also promote the arrangement of a hedonic internet purchasing experience [101].

The contribution of product categories to the variance of each dimension also produce essential proof. Amongst all the product categories, electronics and personal care show a comparatively stronger association with the dimension 1 . The criteria mentioned above are the critical impetus or determinants of the relative positioning of product categories. This finding when corroborated with the contingency table, reveals that the positioning of personal care is influenced with the criterion - product visuals and hedonism whereas positioning of electronics is influenced with discount options.

In dimension 2, the dominant purchase criteria are- delivery time and online reviews. It is similar to an earlier study [46], which found that online consumers rate delivery schedules, delivery guarantees and delivery time as the most critical delivery information they seek online before making a purchase. Wang, Ping, Luping Sun and Luluo Peng [102] revealed in their study the significant impact of online reviews on the product attitude differ significantly across products. A similar study by Jin Ma, Yoon and Hyun-Hwa Lee [103] revealed that consumer trust in reviews is a critical predictor of purchase intentions and final decision making. It will be no surprise if we say that online reviews and recommendations within online feedback system has useful implications for brand building [104]. The positioning of apparels and stationery \& schools/offices supplies are influenced by these criteria.

Table 3.Dimensionality

\begin{tabular}{cccc}
\hline Dimension & Eigen value & $\begin{array}{c}\text { Proportion } \\
\text { explained }\end{array}$ & $\begin{array}{c}\text { Cumulative } \\
\text { proportion }\end{array}$ \\
\hline 1 & .256 & .633 & .633 \\
2 & .160 & .248 & .882 \\
3 & .094 & .085 & .966 \\
4 & .059 & .034 & 1.000 \\
\hline
\end{tabular}


Table 4. A contribution of online product image attributes (rows) and product categories (columns) to dimension variances

\begin{tabular}{|c|c|c|c|c|}
\hline \multirow[t]{2}{*}{ Purchase Criteria } & \multicolumn{2}{|c|}{ Coordinates } & \multicolumn{2}{|c|}{ Dimension } \\
\hline & 1 & 2 & 1 & 2 \\
\hline Discount option & -.183 & .520 & .007 & .095 \\
\hline Exclusive offers & -.716 & .212 & .082 & .012 \\
\hline Comparison option & -.350 & -.411 & .021 & .046 \\
\hline Delivery options & -.324 & .148 & .022 & .007 \\
\hline Delivery time & .070 & -.996 & .001 & .213 \\
\hline Return Policy & .133 & .278 & .005 & .003 \\
\hline Brand availability & -.427 & .256 & .037 & .021 \\
\hline Payment options & -.579 & .086 & .063 & .002 \\
\hline Ease of placing orders & .054 & .095 & .000 & .002 \\
\hline Appropriate price & .245 & .351 & .014 & .046 \\
\hline Sale \& support & -.709 & .050 & .093 & .001 \\
\hline Online review & -.254 & -.764 & .015 & .213 \\
\hline Product varieties & .521 & .541 & .061 & .106 \\
\hline Product visuals & .914 & .310 & .161 & .030 \\
\hline Product information & .012 & -.354 & .000 & .054 \\
\hline Clarity of Market & -.481 & -.020 & .045 & .000 \\
\hline Communication & .950 & -.565 & .209 & .118 \\
\hline Hedonism & -.234 & -.044 & .012 & .001 \\
\hline Image of online player & .840 & .032 & .152 & .000 \\
\hline \multicolumn{5}{|l|}{ Shipment charges } \\
\hline Total & & & 1.000 & 1.000 \\
\hline \multicolumn{5}{|l|}{ Product Categories } \\
\hline Electronics & -.597 & .083 & .328 & .010 \\
\hline Apparels & .454 & .400 & .158 & .197 \\
\hline Personal care & .629 & .137 & .289 & .022 \\
\hline Kitchen appliances & -.444 & .038 & .183 & .002 \\
\hline $\begin{array}{l}\text { Stationery \& school/offices } \\
\text { supplies }\end{array}$ & .273 & -.927 & .042 & .769 \\
\hline Total & & & 1.000 & 1.000 \\
\hline
\end{tabular}

\subsection{Perceptual map}

Further to the discussion in the previous section, Figure 1 depicts the pictorial output developed by correspondence analysis from the data in Table 2 . The perceptual map explains the underlying structure and positioning of the purchase criteria and product categories. The presented graphical output (Figure1) also yields important knowledge about how the products are positioned in the online marketplace. This figure provides critical confirmation of how online consumers perceive products vis. a vis. various purchase criteria. The closer the criterion and category are positioned the more positive is the association between them. For instance, electronics are positioned close to exclusive offers (2), sale and support system (11); kitchen appliances to comparison option (4), clarity of market communication (16), image of online market player (18); apparels to ease of placing orders (10), product variety (13); personal care to product visual (14), appropriate shipment charges (19); and stationery and school/offices supplies to delivery option (5). 


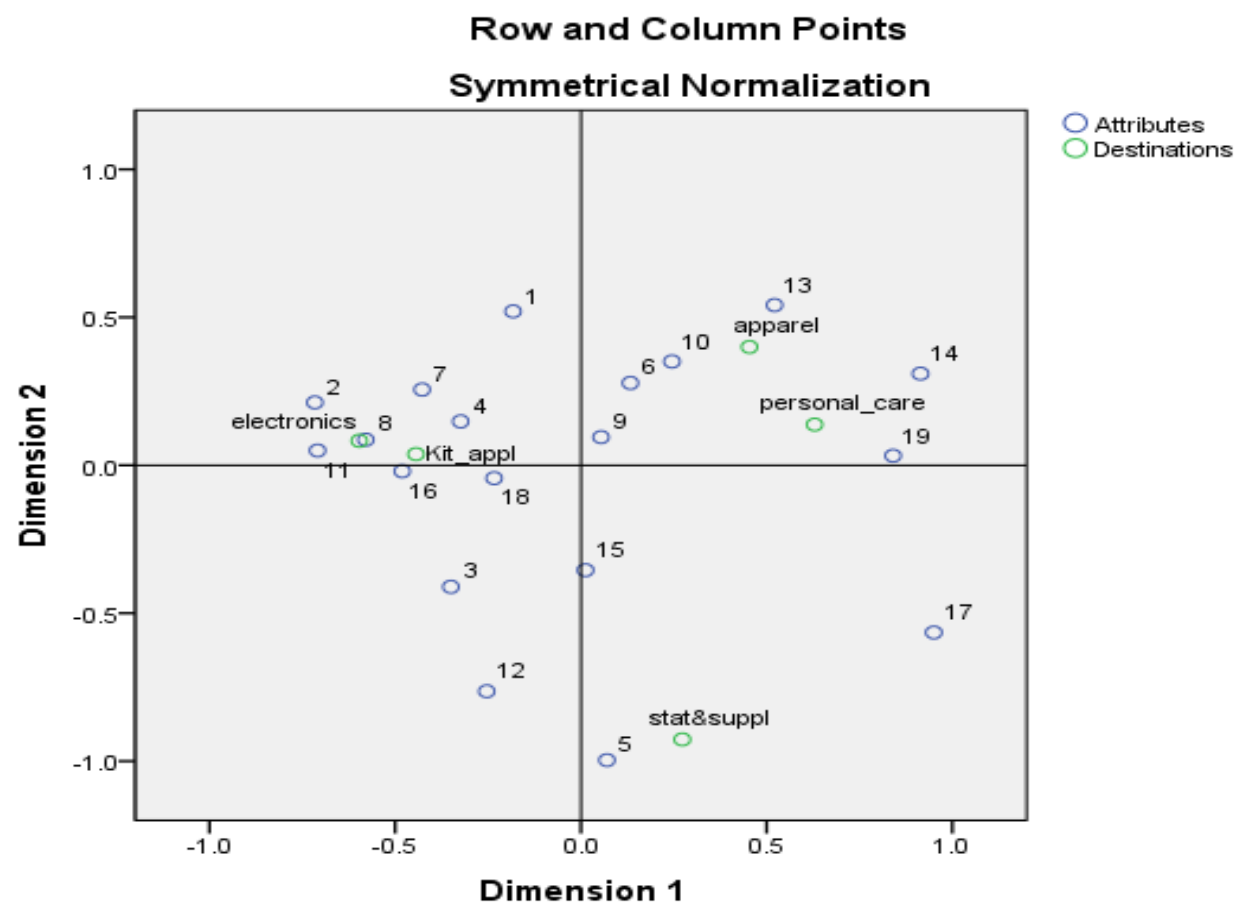

Figure 1. Correspondence map- product categories and purchase criteria

Notes: Key: 1=discount options; 2=exclusive offers; $3=$ comparison options; $4=$ delivery options; $5=$ delivery time; $6=$ return policy; $7=$ brand availability; $8=$ payment options; $9=$ ease of placing orders; $10=$ appropriate price; $11=$ sale and support system ; 12=online reviews; $13=$ product varieties; $14=$ product visuals; $15=$ product information; $16=$ clarity of market communication; 17=hedonism; 18=image of online players; $19=$ appropriate shipment charges.

\subsection{Summary of findings: $R Q 1, R Q 2$ and $R Q 3$}

In summary, we synthesize the findings to address the research questions specifically. RQ 1-Are the product categories-electronics, apparels, personal care, kitchen appliances and stationery \& schools/offices supplies positioned similarly or differently based on the several purchase criteria? The findings which are particularly evident from the perceptual map indicate that the manner in which respondents associate purchase criteria is dissimilar for different product categories. Thus apart from positioning of electronics and kitchen appliances other product categories are distinct particularly stationery and supplies. It means that somewhat similar strategies could be adopted by brands dealing with electronics and kitchen appliances. However for other product categories market offerings have to be contextual to the kind of product categories. Such an analysis helps online market aggregators to design separate strategies to engage the customers and by following an universal approach of announcing discounts and quick delivery (present focus of most online marketers) may not suffice all the time. It is further discussed while addressing the next question.

RQ 2- What are the specific purchase criteria which relate to a particular product category? A major emphasis of this study was to showcase how consumer perceive and associate different purchase criteria with the product categories. It is 
found that criteria such as exclusive offers (2), payment options (8) and sale \& support system (11) show an association with electronics category whereas criteria such as delivery options (4), clarity of market communication (16) and image of online players (18) have an association with kitchen appliances. The criterion such as product variety (13) has an association with apparels product category and criteria such as product visuals (14) and appropriate shipment charges (19) shows an association with personal care. The product category of stationery \& schools/offices supplies has found weak association with most the purchase criteria and is somewhat related to delivery time. Product/brand marketers and marketplace aggregators can draw significant insights by evaluating - which criteria are having an impact on consumers and where the gaps are noticeable by just having a visual inspection of the perceptual map. Out of the nineteen purchase criterion which were employed in this study, only 3-4 criterion associate strongly vis. a vis. each of the product category. Possibly, it breaks down a lot of assumptions that marketers may be having about their marketing strategy such as on the efficacy of discounts and delivery time. They need to pay attention on the criterion where there is a weak association e.g. apparel has a big gap with sale and support system (11) and several other criterion.

RQ 3: Which are the purchase criteria that are discriminatory and have a dominant impact in the positioning of product categories? Findings from Table 4 and the perceptual map (discussed earlier) help us reflect on this question. On a visual inspection it is revealed that purchase criteria which are away from the origin in the perceptual map have a discriminatory influence meaning that they are the ones which have the most dominant role in defining the positioning of various product categories [92]. In this study, the criteria - hedonism (17), online reviews (12), comparison option (3), delivery time (5) and discount options (1) fall in this zone. Online marketers need to particularly focus on these aspects to gain a favorable response from the consumers. The implications of these findings are discussed next.

\section{IMPLICATIONS}

\subsection{Academic implications}

The study is amongst the first to assess the positioning of various product categories on specific purchase criteria for online consumers from tier 2 cities. One of the main theoretical contribution of the study is to depict the potency of correspondence analysis in obtaining a purchase criteria wise comparison of diverse products categories available online. The output of the study is graphical in nature assist an exact and comprehensive analysis of online comparative product positioning. Additionally, the correspondence analysis provides amazing resilience in term of the form of data it can analyze. The only data essential for this technique is a contingency table of non-negative entries [94]. Future researchers can explore the technique for other categories of products too and across different demographic groups. Furthermore, the study by specifically focusing on tier 2 consumer segments addresses the gap in the literature of scant existence of marketing literature which can provide insights in this large and lucrative consumer segment. 


\subsection{Practical implications}

Although, it is a foregone conclusion that consumers across tier 2 segments have a different behavioral pattern than their big city counterparts yet there remains a minimal effort in designing heterogeneous marketing programs for consumers from tier 2 cities. The problem is further compounded due to lack of marketing insights from both- academic and practitioner literature. The results of this study throw light on the same and are discussed below. It may be noted while the study is on product categories the findings are meaningful for different brands within each product category. If they want to create a differentiation with other competing brands in the same category they can gain insight on which of the purchase criteria can be most meaningful and where the gaps exists.

The first insight is for multi-category players (Samsung, Philips etc.) and market space aggregators (like Amazon and Flipkart). Primarily, it can be understood that market strategies cannot be universal for product types when dealing with small town consumers. Replication has to be limited. As we see from the findings consumers relate to the marketing mix in a somewhat similar manner for electronic products and kitchen appliances but for other categories the need is imminent to design separates strategies to market products online. For instance, in regular time or when cyber sales such as Big Billion Days, Valentine's sale etc. are announced most online marketers focus on promoting discounts on smart phones and other electronic items and appliances. Regular and routine items or products (like stationery or personal care) which are commonly available in big cities but may be sought online by small town consumers do not get promoted enough. Features, functions, variety, benefits, return policy etc. are not highlighted in marketing communication. To get an online audience several product categories may require intensive market communication. Local marketing communications - television, radio and print can be customized and made linguistically diverse to hold suitable appeal and engagement with small town consumers.

The findings reveal that some purchase criteria have a dominant role on shaping the position of the products- hedonism, online reviews, comparison option, delivery time and discount options. In particular hedonism (Table 4, dimension 1 and 2) emerges as the most dominant amongst all purchase criteria. Hedonistic pleasure is fun, entertainment, playfulness of shopping experiences. In an online environment, it stirs emotional arousal and can influence consumer engagement. In fact, by virtue of their attention (online) and minus the distractions of brick and mortar shopping like noise, embarrassment or time consumers can fulfill their motives unabashedly. This finds support in past literature. Hedonic value positively affects unplanned buying behavior and prolongs online engagement time [105]. Hedonic dimension has been stated as a necessary element in e-commerce [106], [107]. However, as of now it does not seem as an integral part of online marketing strategies. Bringing in novelty, including chat links, creating a friendly user oriented website design, announcing competitive fun games and quiz, announcing rewards can hold appeal for the hedonic shoppers. The findings reveal that kitchen appliances received the least rating on this. This can be comfortably achieved by strategically designing the website which will give a pleasing visit to online consumers and attractive features like product demonstration video, product comparisons, user opinions etc. should be visibly placed on the sites [108]. Particularly online demonstration videos regarding the use of appliances can encourage engagement when online shoppers can see devices in 
action [109]. Usefulness of online reviews also emerged as one of the key criterion. The power of online reviews \& recommendations and word of mouth (positive or negative) are known to all marketers. Previous literature suggests that online reviews given on a specific product have significant influence on the sales and the sales from the previous period indicate future sales [110], [111]. Consumers value and trust peer opinion higher than seller information [112]. Thus, user generated content can be tactically presented thorough smart algorithms to build a better customer engagement [113]. Timely responding to user queries/comments and encouraging satisfied or loyal consumers to provide product review can be helpful [114]. Comparison options emerged as yet another key criterion. It was found comparatively weaker for apparel and personal care products. Several studies in the past [115], [116], [117], [118], have established that perceived risk is higher for online shoppers. When they are facilitated for making comparisons between their choice of alternatives, it may help allay their fears and validate their decisions [56]. Several sites particularly in the category of electronics provide such options. Online players in case of apparel and personal care may take note of the same. The use of product virtualization technology can benefit them to showcase their products in a comparative manner [119]. Delivery time is another influential factor. It is poorly associated with apparel. An important aspect is that- it is being perceived so - and the actual time may not be hugely different from other categories. The waiting seems to be longer here because many a time it is needed for immediate consumption (e.g. timed with some upcoming occasion). In an earlier study it has been identified that delivery time, delivery schedule and delivery guarantees are the most important purchase criteria online customers evaluate prior to purchase [120]. E-marketers may improve upon their logistic (delivery, reverse delivery) programs to facilitate the same. Last mile connectivity is challenging in a vast country like India and therefore adoption of APM (automated parcel machines) or PUDO (Pick-up Drop-Off) may be successful. These are safe and secure storage space to collect your parcel any time, day or night and serve like a locker. Consumers from tier 2 cities can benefit from these services as it may be helpful to cut short the delivery time and make it more secure. Discount options are also impactful. It may be continued as a part of current strategy. However, stationery \& schools/offices supplies category shows a poor association on the same. Offering discounts on bulk purchase may yield a winning situation for both online buyers and online sellers.

The perceptual map (as discussed - RQ 2) has provided us a meaningful insightpurchase criteria are being associated with product categories in a varied manner. Product information and ease of placing orders are positively associated with most categories. Otherwise strengths and weaknesses vis. a vis. each product categories are somewhat different. There are several noticeable gaps. While, electronics and kitchen appliance are positively associated with a number of criteria such as- exclusive offers, payment options, sale \& support system, delivery options, clarity of market communication and image of online players, however for other categories particularly personal care and stationery \& schools/offices supplies the association is comparatively weak on most. E-marketers have identifiable weakness placed for them that requires work. Although some common aspects have been presented we briefly discuss some aspects category wise. For instance shipment charges are a sore point in case of electronics. Marketers can face a challenging situation if they do not form economical shipment strategies. Extant literature reveals that free shipping reduced customers' perceived ambiguity even when delivery time is lengthy [121]. Ignoring an important purchase criterion such as shipment charges could also trigger cart abandonment. Losing online customers at the last minute- after they have gone to the 
trouble of adding items to their shopping basket- is certainly frustrating for ecommerce retailers [122], [123], [124]. In case of apparels - comparison option, delivery time (discussed previously) and sale and support need attention. Return policy has received a high rating. Although apparels do not require a constant customer service and technical support like electronic items yet some options of customization or alteration may be explored as a strategy. In case of personal care products apart from the common aspects discussed above particular attention may be made to improving market communications. Brand endorsements by regionally popular celebrities, multi-lingual advertisements and prominently communicating the value proposition may yield better success. In case of kitchen appliance consumer expect more product variety and product visuals. On several occasions a model might be available online but is not delivered at several small time locations. Online marketers may lose out on such built up demand and as discussed earlier may improve their logistic support to serve such segments. Perhaps, stationery \& school/offices supplies is a category which is not been given attention by online marketers. There is enough demand for home or office use for modern, fancy and multi-function items and small time equipments which is still not captured well by online marketers. More than $80 \%$ of Indian stationery market is unorganized [80] and most of the domestic demand is being fulfilled by the local market players leaving a lot of potential for eretailers. Yet, the findings demonstrate that expect for delivery time all other purchase criteria are somewhat weakly associated. Bulk discounts particularly for office segment can be a very viable strategy. Thus. across several product categories a number of factors (purchase criteria) may be augmented/improved/technologically facilitated or personalized for strengthening the market position of online players.

\section{CONCLUSION}

Developing economy such as India and China have made noticeable progress in recent years because of modernization and economic reforms. Not just domestic players, international marketers are also attracted to such vast and untapped markets. Therefore, as global competition intensifies and developing countries grow in purchasing power, firms see opportunities for expansion into untapped markets other than metropolitan cities such as tier 2 cities. Tier 2 cities are not only attracting investors or marketers in India but also in other Asian countries such as- Malaysia, China, Indonesia etc. [15]. A leading online player (Lazada) in Malaysia revealed about the noticeable shift in terms of order they are receiving from smaller towns as compare to last few years [125]. Similar trends have been observed in Chinese tier 2 cities where consumers residing in tier 2 cities such as- Tianjin, Hangzhou and Suzhou spend more on e-commerce than big cities [126]. Online marketers in India and similar locations may benefit from redesigning their market offerings in light of the findings from this study.

In this immensely competitive era all marketers strive to create a niche for their brand, product or service by evaluating various purchase criteria such as price, packaging, discounts and after sale services etc. By knowing the current positioning of the product, marketers can develop the distinct and value based positioning ideas and reposition if necessary. This study has provided directions for the same. As the online retail industry in India has an all new target the consumer base from tier 2 cities, it becomes more critical for them to know their online consumers/shoppers association to their design of marketing mix (purchase criteria) with respect to distinct categories of products. The results of this study empower online marketers by 
allowing them to anticipate the same. This also presents an opportunity to take to optimally redesign their strategies viewing the strengths and weaknesses vis. a vis. various factors.

The present study has endeavored to fill some gaps in the online marketing literature in certain ways. This study is amongst the first to measure the association of purchase criteria with different product categories of Indian online consumers from tier 2 cities. Additionally, with the use of correspondence analysis a graphical and easily comprehensible view of the comparative positioning of the product categories is presented. As with most studies this study suffers from some limitations too. Firstly, the study has predominantly male respondents and therefore an imbalanced gender ratio. Secondly the sample size is somewhat smaller (area wise) however since the data was personally collected by one of the authors it lead to a minimum of missing entries and ensured accuracy of records. Even with this limitation, the findings are very useful for online marketers and practitioners as these are the first in the line of research which provides directions for an organized approach in the marketing of online retail in India.

In this research the five product categories and its association with purchase criteria have been evaluated. The study has been carried out in three different cities of northern India i.e. Jalandhar (Punjab), Kota (Rajasthan) and Agra (UP) and it has an area limitation. Future studies may also include more tier 2 cities from rest of the parts of India and comparison can be made between tier 2 and tier 3 /small towns' online consumers on the basis of purchase criteria by employing correspondence analysis. Similarly it can be evaluated with respect to several demographic factors like age, gender, income and occupation. A comparative study of different brand positioning may also provide interesting results.

\section{REFERENCES}

[1] M. A. Hitt, International strategy and institutional environments. Cross Cultural \& Strategic Management, 23(2), p206-215, 2016.

[2] J. Paul, Marketing in emerging markets: a review, theoretical synthesis and extension. International Journal of Emerging Markets, 2019.

[3] E-commerce Industry in India, India Brand Equity Foundation (IBEF). Retrieved on 2018 from https://www.ibef.org/industry/ecommerce-presentation

[4] Amazon Retail India plans to enter 60 smaller cities. Retrieved on 2019 from https://economictimes.indiatimes.com/industry/services/retail/amazon-retailindia-plans-to-enter-60-smaller-cities/articleshow/69017302.cms?from=mdr

[5] India's e-commerce market continue to surge. Retrieved on 2018 from https://www.emarketer.com/newsroom/index.php/indias-ecommerce-marketcontinues-to-surge/

[6] Report of the Seventh Central Pay Commission. Retrieved on 2018 from https://doe.gov.in/sites/default/files/7cpc_report_eng.pdf.

[7] E-commerce has a definite edge over physical retail in tier-II, tier-III cities. Business Line. Retrieved on 2018 from https://www.thehindubusinessline.com/news/e-commerce-has-a-definite-edgeover-physical-retail-in-tier-ii-tier-iii cities/article24870322.ece.

[8] Snapdeal targeted smaller town to draw new online shopper, Best Media info Bureau. Retrieved on 2018 from http://bestmediainfo.com/2018/10/snapdealtargets-smaller-towns-to-draw-new-online-shoppers/ 
[9] Shoppers from Tier II, III cities throng e-commerce sites for festive offers. Retrieved on 2019 from https://economictimes.indiatimes.com/smallbiz/startups/newsbuzz/shoppers-from-tier-ii-iii-cities-throng-e-commerce-sitesfor-festive-offers/articleshow/66206605.cms.

[10] India's growth paradigm: How markets beyond metros have transformed. Retrieved on 2018 from https://www.ey.com/Publication/vwLUAssets/ey-indiasgrowth-paradigm/\$FILE/ey-indias-growth-paradigm.pdf

[11] Demystifying the Indian Online Traveler, Hotels : A Four Billion Opportunity. Retrieved on 2018 from https://media-publications.bcg.com/BCG-GoogleDemystifying-the-Indian-online-traveler-Jun-2017.pdf

[12] E-Travel Marketing India, Octane Researh. Retrieved on 2015 from http://www.octane.in/research/pdf-report/e-Travel-Marketing-India.pdf

[13] India Brand Equity Foundation, Real Estate. Retrieved on 2018 from https://www.ibef.org/download/Real-Estate-January-2018.pdf

[14] Property searches surge $173 \%$ in tier II cities, but still too early to buy. Retrieved on 2018 from https://www.livemint.com/Money/HOQd0j2NzwejusgbbL5UpK/Propertysearches-surge-173-in-tier-II-cities-but-still-to.html.

[15] J. Paul and E. Mas, The emergence of China and India in the global market. Journal of East-West Business, 22(1), p28-50, 2016.

[16] A. Amling and P.J. Daugherty, Logistics and distribution innovation in China. International Journal of Physical Distribution \& Logistics Management, 2018.

[17] G. Arora, The continued momentum of e-commerce growth in China: Report. Retrieved on 2019 from https://www.pwc.in/consulting/financialservices/fintech/fintech-insights/the-continued-momentum-of-e-commercegrowth-in-china.html

[18] K. Todorov and Y.H. Akbar, Contemporary Corporate Strategies, in Krassimir Todorov, Yusaf H. Akbar (ed.) Strategic Management in Emerging Markets, p225 - 281, 2018.

[19] P. Kotler and G. Armstrong, Principle of marketing 14th Ed. , Pearson Education Inc. Prentice Hall, 2011.

[20] T. J. Madden, P. S. Ellen, and I. Ajzen, A comparison of the theory of planned behavior and the theory of reasoned action. Personality and social psychology Bulletin, 18(1), p3-9, 1992.

[21] R. Ashman, M. R. Solomon, and J. Wolny, An old model for a new age: Consumer decision making in participatory digital culture. Journal of Customer Behaviour, 14(2), p127-146, 2015.

[22] N. L. Cassill and M. F. Drake, Apparel selection criteria related to female consumers' lifestyle. Clothing and Textiles Research Journal, 6(1), p20-28, 1987.

[23] N. B. Kanagal, An Extended Model of Behavioural Process in Consumer Decision Making. International Journal of Marketing Studies, 8(4), p87-93, 2016.

[24] P. C. Hollan, Cognitive versus stimulus-response theories of learning. Learning \& behavior, 36(3), p227-241, 2008.

[25] S. Karimi, A purchase decision-making process model of online consumers and its influential factoral cross sector analysis. Thesis University of Manchester, p1326, 2013.

[26] S. Karimi, K. N. Papamichail, and C. P. Holland, Purchase Decision Processes in the Internet Age. In Decision Support Systems III-Impact of Decision Support Systems for Global Environments, Springer, Cham, p57-66, 2013. 
[27] R. Shamser, The Importance Of Product Attributes Influencing Purchase Decision: A Comparative Study Between FMCG Laundry Soaps. DU Journal of Marketing, 5 (15), p231-243, 2012.

[28] J. Kim and S. Forsythe, Hedonic usage of product virtualization technologies in online apparel shopping. International Journal of Retail \& Distribution $\begin{array}{llll}\text { Management, } & 35 & \text { (6), } & \text { p502-514, }\end{array}$ https://doi.org/10.1108/09590550710750368.

[29] R. R. Dholakia and M. Zhao, Effects of online store attributes on customer satisfaction and repurchase intentions. International Journal of Retail \& Distribution Management, $38 \quad$ (7), p482-496, 2010. https://doi.org/10.1108/09590551011052098.

[30] K. E. Millerand J. L. Ginter, An investigation of situational variation in brand choice behavior and attitude. Journal of Marketing research, 16 (1), p111-123, 1979. DOI: $10.2307 / 3150882$.

[31] P. R. Dickson, Person-situation: Segmentation's missing link. Journal of marketing, 46 (4), p56-64, 1982. https://doi.org/10.1177/002224298204600407.

[32] M. J. Houston and M. L. Rothschild, A paradigm for research on consumer involvement, Graduate School of Business, University of Wisconsin-Madison, US, 1977.

[33] D. H. Gensch and R. G. Javalgi, The influence of involvement on disaggregate attribute choice models. Journal of Consumer Research, 14 (1), p71-82, 1987. https://www.jstor.org/stable/1251362.

[34] T. G. Williams and M. E. Slama, Market mavens' purchase decision evaluative criteria: Implications for brand and store promotion efforts. Journal of $\begin{array}{llll}\text { Consumer } & \text { Marketing, } 12 & \text { (3), } & \text { p4-21, }\end{array}$ https://doi.org/10.1108/07363769510147218.

[35] K. P. Corfman, Comparability and comparison levels used in choices among consumer products. Journal of Marketing Research, 28 (3), p368-374, 1991. https://doi.org/10.1177/002224379102800312.

[36] P. Wright and P. D. Rip, Product class advertising effects on first-time buyers' decision strategies. Journal of Consumer Research, 7 (2), p176-188, 1980.

[37] J. R. Bettman and M. Sujan, Research in consumer information processing, in Review in Marketing, ed. Houstan MJ, American Marketing Association, Chicago, p197-235, 1987.

[38] J. EunLee and L. Stoel, High versus low online price discounts: effects on customers' perception of risks. Journal of Product \& Brand Management, 23 (6), p401-412, 2014. https://doi.org/10.1108/JPBM-06-2014-0633.

[39] J. L. Ferguson and P. S. Ellen, Transparency in pricing and its effect on perceived price fairness. Journal of Product \& Brand Management, 22 (5/6), p404-412, 2013. https://doi.org/10.1108/JPBM-06-2013-0323.

[40] L. C. Harris, Fraudulent consumer returns: exploiting retailers' return policies. European Journal of Marketing, 44 (6), p730-747, 2010.

[41] S. K. Mukhopadhyay and R. Setoputro, Reverse logistics in e-business: Optimal price and return policy. International Journal of Physical Distribution \& $\begin{array}{llll}\text { Logistics } \quad \text { Management, } & 34 \quad \text { (1), } & \text { p70-89, }\end{array}$ https://doi.org/10.1108/09600030410515691.

[42] V. Dhar and E. A. Chang, Does chatter matter? The impact of user-generated content on music sales. Journal of Interactive Marketing, 23 (4), p300-307, 2009. https://doi.org/10.1016/j.intmar.2009.07.004. 
[43] C. L. Hsu, C. C. Lin, and H. S. Chiang, The effects of blogger recommendations on customers' online shopping intentions. Internet Research, 23 (1), p69-88, 2013. https://doi.org/10.1108/10662241311295782.

[44] P. Beaudoin, M. A. Moore, and R. E. Goldsmith, Fashion leaders' and followers' attitudes toward buying domestic and imported apparel. Clothing and Textiles Research Journal, 18 (1), p56-64, 2000.

[45] S. Chung, The role of online informediaries for consumers: a dual perspective about price comparison and information mediation. Internet Research, 23 (3), p338-354, 2013. https://doi.org/10.1108/10662241311331763.

[46] K. P. Thomas, G. Moss, D. Chelly and S. Yabin, The provision of delivery information online: a missed opportunity. International Journal of Retail \& Distribution Management, 34(4/5), p258-277, 2006.

[47] M. Kim and S. Lennon, The effects of visual and verbal information on attitudes and purchase intentions in internet shopping. Psychology \& Marketing, 25 (2), p146-178, 2008. https://doi.org/10.1002/mar.20204.

[48] K. Yang and A. P. Young, The effects of customized site features on internet apparel shopping. Journal of Fashion Marketing and Management: An International Journal, $13 \quad$ (1), p128-139, 2009. https://doi.org/10.1108/13612020910939923.

[49] H. McCormick and C. Livett, Analysing the influence of the presentation of fashion garments on young consumers' online behavior. Journal of Fashion Marketing and Management: An International Journal, 16 (1), p21-41, 2012. https://doi.org/10.1108/13612021211203014.

[50] K. Miller, Hedonic customer responses to fast fashion and replicas. Journal of Fashion Marketing and Management: An International Journal, 17 (2), p160174, 2013. https://doi.org/10.1108/JFMM-10-2011-0072.

[51] A. Kaur and P. Thakur, Determinants of Tier 2 Indian consumer's online shopping attitude: a SEM approach. Asia Pacific Journal of Marketing and Logistics, 2019.

[52] K. Peighambari, S. Sattari, A. Kordestani, and P. Oghazi, Consumer behavior research: A synthesis of the recent literature. SAGE Open, 6(2), p1-9, 2016.

[53] Y. Bae and H. Chang, Adoption of smart TVs: a Bayesian network approach. Industrial Management \& Data Systems, 112(6), p891-910, 2012.

[54] S. T. Luk, I. S. N. Chen and J. Coombes, Skyworth TV: channel dynamics and growth in China's rural market. Emerald Emerging Markets Case Studies, 3(4), p1-13, 2013.

[55] I. Mashal and A. Shuhaiber, What makes Jordanian residents buy smart home devices? A factorial investigation using PLS-SEM. Kybernetes, 2018.

[56] K. Smoliana, Consumer behavior towards buying consumer electronics online: cross-national analysis. Master's thesis, Nord university, 2017.

[57] J. Kim and S. Forsythe, Factors affecting adoption of product virtualization technology for online consumer electronics shopping. International Journal of Retail \& Distribution Management, 38 (3), p190-204, 2010.

[58] E. Browntape, What selles most in the Indian ecommerce market?. Retrieved on 2017 from http://indianonlineseller.com/2017/02/what-sells-most-in-the-indianecommerce-market/

[59] D. Biswas, Smartphones, gold, electronics and more-what India is buying online this Diwali. Retrieved on 2018 from https://yourstory.com/2018/11/india-buyingonline-diwali-ecommerce 
[60] G. K. Deshmukh and R. P. Das, Consumer Buying Behaviour for High Involvement Products-A Study. Asian Journal of Management, 3 (3), p153-157, 2012.

[61] D. H. Park and J. Lee, eWOM overload and its effect on consumer behavioral intention depending on consumer involvement. Electronic Commerce Research $\begin{array}{lllll}\text { and Applications, } & 7 & \text { (4), } & \text { p386-398, } & \end{array}$ https://doi.org/10.1016/j.elerap.2007.11.004

[62] M. Mann and S. E. Byun, Accessing opportunities in apparel retail sectors in India: Porter's Diamond approach. Journal of Fashion Marketing and Management: An International Journal, 15 (2), p194-210, 2011.

[63] N. Rajput, S. Kesharwani and A. Khanna, Dynamics of female buying behaviour: a study of branded apparels in India. International Journal of Marketing Studies, 4 (4), p121-129, 2012. doi/10.5539/ijms.v4n4p121

[64] T. L. Childers, C. L. Carr, J. Peck and S. Carson, Hedonic and utilitarian motivations for online retail shopping behavior. Journal of retailing, 77 (4), p511-535, 2001. https://doi.org/10.1016/S0022-4359(01)00056-2.

[65] M. Limayem, M. Khalifa and A. Frini, What makes consumers buy from Internet? A longitudinal study of online shopping. IEEE Transactions on Systems, Man, and Cybernetics-Part A: Systems and Humans, 30 (4), p421-432, 2000.

[66] S. Bellman, G. Lohse and E. J. Johnson, Predictors of online buying behavior. Communication of ACM, 42 (12), p32-38, 1999.doi/10.1145/322796.322805.

[67] Best-selling products online in India for your eCommerce store ideas. eCommerce Product ideas, EWDC. Retrieved on 2016 fromhttps://www.ecommercewebsitedevelopmentchennai.in/blog/10-bestselling-products-online-in-india/

[68] J. Juggessur and G. Cohen, Is fashion promoting counterfeit brands?. Journal of Brand management, $16 \quad$ (5-6), p383-394, 2009. https://doi.org/10.1057/bm.2008.46.

[69] D. Scarpi, Fashion stores between fun and usefulness. Journal of Fashion Marketing and Management: An International Journal, 10 (1), p7-24, 2006. https://doi.org/10.1108/13612020610651097.

[70] Y. Gabriel, and T. Lang, The unmanageable consumer, SAGE Publications Ltd., UK, 2015.

[71] S. Cho and J. Workman, Gender, fashion innovativeness and opinion leadership, and need for touch: Effects on multi-channel choice and touch/non-touch preference in clothing shopping. Journal of Fashion Marketing and Management: An International Journal, 15 (3), p363-382, 2011.

[72] Mintel, Fashion Online. Mintel International, Chicago, IL, www.mintel.com., 2009.

[73] O. Sarpila and P. Räsänen, Personal care consumption in Finland: trends in the early 2000s.International Journal of Sociology and Social Policy, 31(7/8), p441455, 2011. https://doi.org/10.1108/01443331111149879.

[74] S. Pudaruth, T. D. Juwaheer and Y. D. Seewoo, Gender-based differences in understanding the purchasing patterns of eco-friendly cosmetics and beauty care products in Mauritius: a study of female customers. Social responsibility journal, 11 (1), p179-198, 2015. https://doi.org/10.1108/SRJ-04-2013-0049.

[75] N. Souiden and M. Diagne, Canadian and French men's consumption of cosmetics: a comparison of their attitudes and motivations. Journal of Consumer marketing, 26 (2), p97-109, 2009. https://doi.org/10.1108/07363760910940465. 
[76] M. Guthrie, H. S. Kim and J. Jung, The effects of facial image and cosmetic usage on perceptions of brand personality. Journal of fashion marketing and management: an international journal, 12 (2), p164-181, 2008.

[77] E. B. Silva, The cook, the cooker and the gendering of the kitchen. The Sociological Review, 48 (4), p612-628, 2000.

[78] W. C. Cockerham, Health lifestyle theory in an Asian context. Health Sociology Review, 15 (1), p5-15, 2006. https://doi.org/10.5172/hesr.2006.15.1.5.

[79] W. M. Hur, H. K. Kim and J. K. Park, Food-and situation-specific lifestyle segmentation of kitchen appliance market. British Food Journal, 112 (3), p294305, 2010. https://doi.org/10.1108/00070701011029165.

[80] S. Oswal ,Industry Analysis of the Stationery Sector in India: A Market Acceptance Study. Business and Economics Journal, 5 (3), p1-11, 2014.

[81] C. Del, M. Ricardo and Braun, Framework for effective brand communication for pen development. International Journal of Research in Commerce, Economics and Management, 1, p1-155, 2006.

[82] I. Etikan, S. A. Musa and R. S. Alkassim, Comparison of convenience sampling and purposive sampling. American journal of theoretical and applied statistics, 5 (1), p1-4, 2016.

[83] S. Hooda and S. Aggarwal, Consumer behaviour towards e-marketing: A study of Jaipur consumers. Researchers World, 3 (2), p107-118, 2012.

[84] Z. M. Jusoh and G. H. Ling, Factors influencing consumers' attitude towards ecommerce purchases through online shopping. International Journal of Humanities and Social Science, 2 (4), p223-230, 2012.

[85] S. Das, Tier II, III cities are the next retail destinations in the country: Report. Retrieved on 2017 from https://retail.economictimes.indiatimes.com/news/industry/tier-ii-iii-cities-arethe-next-retail-destinations-in-the-country-report/61876688.

[86] P. Thakur and A. Kaur, Tier 2 Consumers' Online Segmentation- Insights from an Empirical Study in India. ELK's International Journal of Marketing and Retailing, 10 (1), p74-95, 2019. DOI: 10.16962/EAPJMRM/issn. 2349 2317/2018.

[87] P. Thakur and A. Kaur, Online Shopping Attitude of Indian Tier 2 Consumers: Some Qualitative Insights. International Journal of Online Marketing (IJOM), 9(2), p13-26, 2019.

[88] Fitness, lifestyle products top online shopping in Punjab, SupportBiz. Retrieved on 2013 from http://www.supportbiz.com/articles/news/fitness-lifestyleproducts-top-online-shopping-punjab.html

[89] India Retailing. Retrieved on 2018 from "eBay India Census report", http://www.indiaretailing.com/uploads/banner_pdf/eBay_Census_Report_2014_ Final.pdf.

[90] A business venture of MapsofIndia.com. Retrieved on 2018 from http://www.mapsofagra.com/shopping/online-shop.html.

[91] Kota becomes India's top coaching city with annual turnover of 1500 crore, India Today. Retrieved on 2017 from https://www.indiatoday.in/educationtoday/news/story/kota-medical-969821-2017-04-06.

[92] M. Greenacre, Correspondence analysis in practice. Chapman and Hall/CRC Taylor \& Francis group, Broken sound parkway, New York, 2017.

[93] W. C. Johnson, Current research in phytolith analysis: applications in archaeology and paleoecology. Deborah M. Pearsall and Delores R. Piperno, University Museum of Archaeology and Antropology, University of Pennsyvalina, 10, p212, 1993. https://doi.org/10.1002/gea.3340100504. 
[94] U. Yavas and D. J. Shemwell, Bank image: exposition and illustration of correspondence analysis. International Journal of Bank Marketing, 14 (1), p1521, 1996. https://doi.org/10.1108/02652329610105288.

[95] M. Mazzocchi, Statistics for marketing and consumer research. SAGE Publications Ltd, 2008.

[96] A. Kaur, A. Chauhan, and Y. Medury, Destination image of Indian tourism destinations: An evaluation using correspondence analysis. Asia Pacific Journal of Marketing and Logistics, 28(3), p499-524, 2016.

[97] M.O. Hill, Correspondence analysis: a neglected multivariate method. Journal of the Royal Statistical Society: Series C (Applied Statistics), 23(3), p340-354, 1974.

[98] I.P. Chiang, C.Y. Lin, and Y.J. Wu, Exploring Smartphone Users' Social Information Behavior. Contemporary Management Research 15 (1), p53-67, 2019.

[99] D. L. Hoffman and G. R. Franke, Correspondence analysis: graphical representation of categorical data in marketing research. Journal of marketing Research, 23 (3), p213-227, 1986. https://www.jstor.org/stable/3151480.

[100] B. Hernandez, J. Jimenez and M. J. Martín, Adoption vs acceptance of ecommerce: two different decisions. European Journal of Marketing, 43(9/10), p1232-1245, 2009. https://doi.org/10.1108/03090560910976465.

[101] J. Oh, S. S. Fiorito, H. Cho, and C. F. Hofacker, Effects of design factors on store image and expectation of merchandise quality in web-based stores. Journal of Retailing and Consumer Services, 15 (4), p237-249, 2008.

[102] P. Wang, L. Sun, and L. Peng, Modeling product attitude formation process in online word-of-mouth. Nankai Business Review International, 4 (3), p212-229, 2013. https://doi.org/10.1108/NBRI-07-2013-0025.

[103] Y. JinMa and H. H. Lee, Consumer responses toward online review manipulation. Journal of Research in Interactive Marketing, 8 (3), p224-244, 2014.

[104] C. Dellarocas, The digitization of word of mouth: Promise and challenges of online feedback mechanisms. Management science, 49 (10), p1407-1424, 2003. https://doi.org/10.1287/mnsc.49.10.1407.17308.

[105] C. H. Lee and J. J. Wu, Consumer online flow experience: the relationship between utilitarian and hedonic value, satisfaction and unplanned purchase. Industrial Management \& Data Systems, 117(10), p2452-2467, 2017.

[106] M. Del Mar Alonso-Almeida, M. Bernardo, J. Llach, and F. Marimon, Building loyalty through functional and hedonic quality. Industrial Management \& Data Systems, 114(3), p387-404, 2014.

[107] S. Ottar Olsen and K. Skallerud, Retail attributes' differential effects on utilitarian versus hedonic shopping value. Journal of Consumer Marketing, 28(7), p532-539, 2011.

[108] C. Dennis, T. King, J. Kim, and S. Forsythe, Hedonic usage of product virtualization technologies in online apparel shopping. International Journal of Retail \& Distribution Management, 35(6), p502-514, 2007.

[109] L. Barnes, G. Lea-Greenwood, and K. Miller, Hedonic customer responses to fast fashion and replicas. Journal of Fashion Marketing and Management: An International Journal, 2013.

[110] L. Zhang, B. Ma, and D. K. Cartwright, The impact of online user reviews on cameras sales. European Journal of Marketing, 47(7), p1115-1128, 2013.

[111] A. Y. L. Chong, B. Li, E. W. Ngai, E. Chng, and F. Lee, Predicting online product sales via online reviews, sentiments, and promotion strategies: A big 
data architecture and neural network approach. International Journal of Operations \& Production Management, 36(4), p358-383, 2016.

[112] H. Kim and J. Song, The quality of word-of-mouth in the online shopping mall. Journal of Research in Interactive Marketing, 4(4), p376-390, 2010.

[113] H. Hong, D. Xu, D. Xu, G. A. Wang, and W. Fan, An empirical study on the impact of online word-of-mouth sources on retail sales. Information Discovery and Delivery, 45(1), p30-35, 2017.

[114] P. Wang, L. Sun, and L. Peng, Modeling product attitude formation process in online word-of-mouth. Nankai Business Review International, 4(3), p212-229, 2013.

[115] C. Bezes, Comparing online and in-store risks in multichannel shopping. International Journal of Retail \& Distribution Management, 44 (3), p284-300, 2016. https://doi.org/10.1108/IJRDM-02-2015-0019.

[116] A. D. Miyazakiand A. Fernandez, Consumer perceptions of privacy and security risks for online shopping. Journal of Consumer affairs, 35 (1), p27-44, 2001. https://doi.org/10.1111/j.1745-6606.2001.tb00101.x

[117] A. F. Salam, H. R. Rao and C. C.Pegels, Consumer-perceived risk in ecommerce transactions. Communications of the ACM, 46 (12), p325-331, 2003.

[118] L. Swiegers, Perceived risk barriers to online shopping: experiences of technologically enabled generation y consumers. Doctoral dissertation, Stellenbosch: Stellenbosch University, 2018.

[119] J. Yoo and M. Kim, Online product presentation: the effect of product coordination and a model's face. Journal of Research in Interactive Marketing, 6(1), p59-72, 2012.

[120] K. Page-Thomas, G. Moss, D. Chelly, and S. Yabin, The provision of delivery information online: a missed opportunity. International Journal of Retail \& Distribution Management, 34(4/5), p258-277, 2006.

[121] S. Ma, Fast or free shipping options in online and omni-channel retail? The mediating role of uncertainty on satisfaction and purchase intentions. The International Journal of Logistics Management, 28(4), p1099-1122, 2017.

[122] J. Cho, Likelihood to abort an online transaction: influences from cognitive evaluations, attitudes, and behavioral variables. Information \& Management, 41 (7), p827-838, 2004. https://doi.org/10.1016/j.im.2003.08.013.

[123] M. Krithika and G. Rajini, Persuading Attributes of Online Shopping Cart Abandonment. International Journal of Engineering \& Technology, 7 (3), p739742, 2018. doi/10.14419/ijet.v7i3.34.19464.

[124] R. F. Muster, Online shopping abandonment rate a new perspective: the role of choice conflicts as a factor of online shopping abandonment. Master's thesis, University of Twente, 2016.

[125] Retail News Asia, A Short Overview of Malaysian Shopping Trends. Retrieved on 2019, from https://www.retailnews.asia/29206/

[126] Rising opportunities in Chinese Tier 2 Cities. Retrieved on 2018, from https://www.1421.consulting/2018/05/chinese-tier-2-cities/ 